\title{
Immunomodulatory Effect of Purified Exotoxins of Staphylococcus aureus in Association with Bird Flu Virus Vaccine in Broilers
}

\author{
Muhammad Usman Ghani', Muhammad Danish Mehmood ${ }^{*}$, Amna Javed1, Farheen Ansari², \\ Huma Anwar1, Sana Noreen', Sajjad Hussain Shah' \\ ${ }^{1}$ Ottoman Pharma (Immuno Division), Lahore, Pakistan \\ ${ }^{2}$ Institute of Molecular Biology and Biotechnology, University of Lahore, Lahore, Pakistan \\ Email: *drdanishmehmood@gmail.com
}

How to cite this paper: Ghani, M.U., Mehmood, M.D., Javed, A., Ansari, F., Anwar, H., Noreen, S. and Shah, S.H. (2019) Immunomodulatory Effect of Purified Exotoxins of Staphylococcus aureus in Association with Bird Flu Virus Vaccine in Broilers. American Journal of Molecular Biology, 9, 1-15.

https://doi.org/10.4236/ajmb.2019.91001

Received: October 13, 2018

Accepted: November 24, 2018

Published: November 27, 2018

Copyright () 2019 by authors and Scientific Research Publishing Inc. This work is licensed under the Creative Commons Attribution International License (CC BY 4.0).

http://creativecommons.org/licenses/by/4.0/

\begin{abstract}
Immunization is the most effective method still used against infectious agents. Although not always, vaccines ineffectiveness is reported enormously against many of the pathogens throughout the world in poultry, particularly in case of killed or sub unit vaccine. The current project is, therefore, carried out as a preliminary study on broiler chickens to investigate the modulation of immune system against avian influenza virus in association with purified Staphylococcus aureus toxoid. After isolation of Gram positive cocci bacteria on mannitol salt agar from raw milk, yogurt and chicken meat were subsequently biochemically characterized by using rapid diagnostic kit. Pure culture of $S$. aureus was inoculated into digitally controlled bio-fermentor containing mannitol salt broth for production of toxins. Enormous production of bacteria was passed through sequence of filtration system based on $0.45 \mu \mathrm{m}$ followed by $0.22 \mu \mathrm{m}$ size. The centrifugation of the filtrate was made at 10,000 $\mathrm{rpm}$ for 60 minutes at $5^{\circ} \mathrm{C}$ followed by $56,100 \mathrm{rpm}$ for 20 minutes and clear supernatant containing Staphylococcus enterotoxin (SEs) was obtained. Bradford estimation of proteins further provided $305 \mu \mathrm{g} / \mathrm{ml}$ of SEs toxoid. Four types of oil adjuvant avian influenza type H9N2 virus vaccines (without toxoid, $91.5 \mu \mathrm{g} / 0.3 \mathrm{ml}, 22.8 \mu \mathrm{g} / 0.3 \mathrm{ml}$ and $11.43 \mu \mathrm{g} / 0.3 \mathrm{ml}$ ) were injected into healthy AI H9N2 susceptible broilers and anti-H9N2 HI antibody titers were measured in terms of hemagglutination inhibition test. It was observed that on the $8^{\text {th }}$ day, post vaccination cumulative mean anti AIH9 $\mathrm{HI}$ antibody titer of G-1, G-2, G-3, G-4 and G-5 was $3.13 \pm 0.406,5.13 \pm 0.246,3.96 \pm 0.159$, $3.25 \pm 0.237$ and $0.78 \pm 0.467$ respectively. It was found that all the vaccines induced protective titers 18 days' post vaccination, but vaccine containing
\end{abstract}


$91.5 \mu \mathrm{g} /$ dose of SEs toxoid showed significantly higher $(\mathrm{P}<0.05)$ immune response as compared to vaccine containing $22.8 \mu \mathrm{g} / \mathrm{dose}$ and $11.43 \mu \mathrm{g} / \mathrm{dose}$, whereas, vaccines containing SEs toxoid showed better $(\mathrm{P}<0.05)$ anti AIH9 $\mathrm{HI}$ antibody titer as compared to vaccine without SEs toxoid. Thus, it is concluded that addition of super antigens of SEs in the form of toxoids, particularly in inactivated vaccines, could be the better choice for modulation of immediate and better immune response in future vaccines technologies.

\section{Keywords}

AIV H9N2, Staphylococcus aureus Toxoid, Super Antigen, Immunomodulation, HI Assay

\section{Introduction}

Immunization is a process in which a person is made resistant or been protected against particular organism or disease. Vaccination is one of the commonly used defensive strategies against different pathogens depending upon the biochemical nature of the organism and its mechanism of action inside the host, whereas immunomodulation is a process in which immune response is or can be transformed to a desired level [1]. Some bacteria, such as Staphylococcus aureus, produce specialized proteins which auscultate the proliferation of lymphocytes bypassing the antigen presentation mechanism during process of immunogenesis [2]. These are called Super Antigens (SAgs) and released by different types of bacteria like Staphylococcus aureus enterotoxins that are super antigens as mentioned above, like wise Streptococcus pyogenes toxins and Staphylococcal toxic shock syndrome toxins (TSST-1). All types of Staphylococcal Exotoxins (SEs), Streptococcal Pyrogenic Exotoxins (SPEs), and toxic shock syndrome toxins TSST-1 have ability to proliferate the lymphocytes. The $S$. aureus produces enterotoxins (SEs) which are powerful gastrointestinal exotoxins. $S$. aureus releases the enterotoxins during the log phase of growth or throughout the conversion from log phase to the stationary phase. Exotoxins are resistant to those conditions (heat and low $\mathrm{pH}$ ) that simply destroy the bacteria that are producing the exotoxins. They are also resistant to proteolytic enzymes [3].

Staphylococcus aureus releases more than 20 types of exotoxins that behave like super antigens. In this study, we target enterotoxin B of the $S$. aureus. The enterotoxin $\mathrm{B}$ also augments the $\mathrm{T}$ cell activation in such way that uncontrolled cloning of B lymphocytes takes place without any negative feedback mechanism which leads to the production of cytokines and ultimately to the histamine producing cell, such as mast cell and basophils. This mechanism of super antigen for induction of immune response working in a hysterical way helps us to design an experiment to evaluate the effect of these purified proteins in control environment. Therefore, the current study was designed to investigate the effect of $S$. aureus super antigen exotoxin in combination with avian influenza virus inacti- 
vated oil based vaccine.

\section{Materials and Methods}

\subsection{Isolation of Bacteria}

Staphylococcus aureus was isolated from the samples of raw milk, yogurt and chicken meat collected from different areas of Lahore city in Pakistan. Fresh samples were obtained in the $50 \mathrm{ml}$ labelled sterile plastic containers packed with dry ice and transported to the Biotechnology laboratory center of Research in Molecular Medicine, the University of Lahore. Each of the samples was streaked on Manitol salt agar (MSA) and incubated the plates at $37^{\circ} \mathrm{C}$ for 24 hours to get pure culture of the bacteria. After 24 hours' incubation each of the isolated colonies was subjected for the preparation of Grams staining and subsequently microscopy.

\subsection{Identification of the Isolate}

Loopful pure culture of freshly grown G + ve cocci in Manitol salt agar was subjected for biochemical identification using STAPH PLUS System (THERMO SCIENTIFIC, Remel RapID ${ }^{\mathrm{m} w}$ ) rapid diagnostic kit. Sample suspension was inoculated as directed by manufacturer.

\subsection{Bacterial Fermentation and Toxin Production}

Loopful pure culture of Staphylococcus aureus was inoculated into two-liter sterile container containing Manitol salt broth (HI-MEDIA ${ }^{\oplus}$, INDIA.) of digitally controlled Bio-fermenter (Bioengineering RALF Switzerland). Optimum physiochemical requirements such as $24 \mathrm{rpm}, 28 \mathrm{rpm}, 32$, and 45 of agitation, aeration, $\mathrm{pH}$, time and temperature were provided respectively to get maximum growth of bacteria and subsequently toxin production as described by [4].

\subsection{Purification of Staphylococcal aureus Enterotoxins (SEs)}

The purification of the staphylococcal enterotoxins released during log phase of the bacterial fermentation process was done by sequel filtration using $0.45 \mu \mathrm{m}$ followed by $0.2 \mu \mathrm{m}$ pore size paper filters. The filtrate was further centrifuged at high speed and the pellet was decanted and clear supernatant was subjected for the quantitative estimation of the toxins. One liter of fermented bacterial culture suspension was filtered through $0.4 \mu \mathrm{m}$ size paper filter (SARTORIUS STEDIM, GERMANY) the filtrate was again passed through $0.2 \mu \mathrm{m}$ (SARTORIUS STEDIM, GERMANY) filter and finally get $500 \mathrm{ml}$ of bacteria free filtrate. The centrifugation of the filtrate was made at $10,000 \mathrm{rpm}$ for 60 minutes at $5^{\circ} \mathrm{C}$ followed by $56,100 \mathrm{rpm}$ for 20 minutes as described by [5] and clear supernatant containing SEs were stored at refrigerator temperature till further use.

\subsection{Estimation of SEs}

Quantitative estimation of SES was performed by using BRADFORD standard 
method for protein estimation. One $\mathrm{ml}$ of the centrifuged supernatant of fresh $S$. aureus bacterial fermented sample was reacted with Bradford regent as described by [6]. Standard curve was prepared using bovine serum albumin as standard.

\subsection{Identification of Staphylococcal Enterotoxins by Sds-Page}

S. aureus free suspension was subject to SDS-PAGE for the identification and presence of different toxins. Three different dose such as $20 \mu \mathrm{l}, 40 \mu \mathrm{l}$ and $60 \mu \mathrm{l}$ of crude extracted toxin of Staphylococcus aureus along with standard marker (SeeBlue $^{\circledast}$ Invitrogen ${ }^{\text {tx }}$ USA) were loaded into the freshly prepared stacking gel which travels towards the resolving gel after providing current of $80 \mathrm{~V}$ for former and $120 \mathrm{~V}$ for later in the $1 \mathrm{X}$ running buffer (Table 1 ).

Removed the gel from apparatus and dipped in to the box containing staining solution and placed onto the shaker for one hour. After one hour discard the staining solution and added de-stain solution and left the gel for overnight to remove excessive and extra stain from gel.

\subsection{Preparation of SEs Toxoid}

Staphylococcal Enterotoxins was treated with $0.5 \%$ formaldehyde solution and incubated at $37^{\circ} \mathrm{C}$ for 24 - 48 hours to make them toxoid as described by [7].

\subsection{Killed Virus Antigen}

$200 \mathrm{ml}$ of inactivated Avian Influenza Virus H9N2 [8] on the official written request of Director, University of Lahore from Ottoman Pharma Immuno Division situated at Raiwind Road, Lahore.

Biological titer: 512 (1:512) HA unit.

Infectivity titer: $10^{9.5} / \mathrm{ml} \mathrm{EID}_{50}$.

\subsection{Prepartion of Inactivated Oil Based Influenza Vaccine}

Oil based inactivated AIV vaccine was prepared as described by adjuvant manufacturer. For each vaccine, following Table 2 containing "Montanide ISA 70 MVG (SEPPIC, FRANCE)" to aqueous ratio along with SEs toxoid was sheared at $2700 \mathrm{rpm}$ to get homogeneous emulsion. Table 3 describes actual quantity of the antigen to toxoid ratio.

Moreover, Thiomersal sodium (Bio-WORLD, USA.) was added at $0.15 \mathrm{mg} / \mathrm{ml}$ as a preservative in each of the vaccine and whole manufacturing process was performed in Class II Biohazard Biosafety cabinet by using all sterilized instruments and glass wares.

Table 1. Different concentrations of sample.

\begin{tabular}{ccccc}
\hline Sr. \# & Sample $(\mu \mathrm{l})$ & D.H2O $(\mu \mathrm{l})$ & 5X Loading Dye $(\mu \mathrm{l})$ & Total volume $(\mu \mathrm{l})$ \\
\hline 1 & 20 & 60 & 20 & 100 \\
2 & 40 & 40 & 20 & 100 \\
3 & 60 & 20 & 20 & 100 \\
\hline
\end{tabular}


Table 2. Montanide ISA 70 MVG to aqueous ratio.

\begin{tabular}{cccc}
\hline Vaccine & Montanide (ISA 70 MVG) & Inactivated antigen & SEs Toxoid \\
\hline Vaccine A & 60 Parts & 40 Parts & 00 Parts \\
Vaccine B & 60 Parts & 35 Parts & $05(1525 \mu \mathrm{g} / 5 \mathrm{ml})$ \\
Vaccine C & 60 Parts & 35 Parts & $05(381 \mu \mathrm{g} / 5 \mathrm{ml})$ \\
Vaccine D & 60 Parts & 35 Parts & $05(190.5 \mu \mathrm{g} / 5 \mathrm{ml})$ \\
\hline
\end{tabular}

Table 3. Preparation of vaccines.

\begin{tabular}{|c|c|c|c|c|c|c|}
\hline Sr. \# & Vaccines & $\begin{array}{l}\text { Antigen } \\
\text { AIV H9 }\end{array}$ & $\begin{array}{c}5 \mathrm{ml} \\
(\text { Toxoid + N.S) }\end{array}$ & $\begin{array}{l}\text { Toxoids } \\
\text { Per } 5 \mathrm{ml}\end{array}$ & Adjuvant & $\begin{array}{c}\text { Total } \\
\text { Volume }\end{array}$ \\
\hline 1. & Vaccine 1 & $40 \mathrm{ml}$ & - & - & $60 \mathrm{ml}$ & $100 \mathrm{ml}$ \\
\hline 2. & Vaccine 2 & $35 \mathrm{ml}$ & $\begin{array}{c}5 \mathrm{ml} \text { toxoid } \\
\text { concentrated }\end{array}$ & $1525 \mu \mathrm{g}$ & $60 \mathrm{ml}$ & $100 \mathrm{ml}$ \\
\hline 3. & Vaccine 3 & $35 \mathrm{ml}$ & $5 \mathrm{ml}(0.62+4.38)$ & $381 \mu \mathrm{g}$ & $60 \mathrm{ml}$ & $100 \mathrm{ml}$ \\
\hline 4. & Vaccine 4 & $35 \mathrm{ml}$ & $5 \mathrm{ml}(0.31+4.69)$ & $190.5 \mu \mathrm{g}$ & $60 \mathrm{ml}$ & $100 \mathrm{ml}$ \\
\hline
\end{tabular}

\subsection{Quality Control Testing}

AIVH9 inactivated Oil based vaccine was subjected for the following quality control tests:

Drop test: One drop of vaccine was dropped on the surface of water for the detection of type of emulsion.

Microscopy: A loopful drop of vaccine was spread on the sterile slide and observed under 40X lens of microscope (Olympus BH2 Compound Microscope, UK) for distribution of particles in the suspension.

Viscosity: $100 \mathrm{ml}$ of the emulsion was measured for viscosity with the help of digital viscometer (NDJ-8S Viscometer, CHINA).

Stability: It is evaluated by centrifugation of $10 \mathrm{ml}$ of sample at $5000 \mathrm{rpm}$ for 30 minutes (80-3 Centrifuge, CHINA).

\subsection{Experimental Design}

50-day old broilers were purchased from poultry breeding company and reared at experimental animal house of Ottoman Pharma located at Raiwind road, Lahore. The birds were divided into five groups each containing ten birds identified by their respective color. Each of the bird in every group was injected with $0.3 \mathrm{ml}$ of the respective vaccine on $7^{\text {th }}$ day of age through subcutaneous route. Group-1 (G1), Group-2 (G2), Group-3 (G3), Group 4 (G4) was injected with V1, V2, V3 and V4 respectively whereas, Group 5 (G5) was kept as unvaccinated control Table 4.

\subsection{Evaluation of the Vaccines in Association with Immunomodulatory Effect of SEs}

\subsubsection{Collection of Blood Samples}

$1.5 \mathrm{ml}$ of blood from each of the bird of every group was collected on $8,16,32$ and 40 days' post vaccination in sterile $3 \mathrm{cc}$ syringes. The blood containing sy- 
ringes were placed in an incline position at room temperature overnight for the separation of the serum itself. Separated serum were transferred into sterile 1.5 $\mathrm{ml}$ microfuge tubes and stored the serum samples at $-60^{\circ} \mathrm{C}$ freezer (WISECRYO WUF-80, KOREA.) in $\mathrm{R} \& \mathrm{D}$ section of the Ottoman Pharma until further processing for Hemagglutination Inhibition test. All the samples were subjected for $\mathrm{HI}$ and the results were recorded.

\subsubsection{Hemagglutination Inhibition Test}

Serum samples were subjected to Hemagglutination Inhibition for the detection of anti-influenza H9N2 antibody titers according to 96 well plate dilution distribution (Table 5) using test as described by [9].

\section{Results and Discussion}

Small rounded and translucent colonies with regular margins were recovered on tryptic soya agar after 24 hours' incubation at $37^{\circ} \mathrm{C}$. Whereas, pure culture of the bacteria converted red coloration of Manitol salt agar into yellow. On microscopy Gram positive cocci were observed under 100X oil immersion lens. Biochemical identification using analytical profile index (THERMO SCIENTIFIC, Remel RapID $^{\text {tw }}$ ) revealed that \#3 McFarland units of bacterial suspension is positive for test codes of L-Arginine (ADH), Lipase (LIP), Sucrose (SUC), Mannose (MANO), $\rho$-Nitrophenyl-phosphate (PO4), $\rho$-Nitrophenyl- $\alpha$-D-glucoside (aGLU), $\rho$-Nitrophenyl- $\beta$-D-glucoside ( $\beta$ GLU), $\rho$-Nitrophenyl-N-acetyl- $\beta, \mathrm{D}$-glucosaminide (NAGA), Urea (URE), Arginine- $\beta$-naphthylamine (ARG) and Potassium nitrate (NIT) showed purple/blue, yellow/orange, yellow/orange, yellow/orange, pale yellow, light yellow, yellow, yellow, red, purple/light red/dark pink and Cherry red colors respectively in the wells. Whereas, the same suspension was declared as negative for test codes L-Ornithine (ODC), $\sigma$-Nitrophenyl- $\beta$-D-galactoside (ONPG), $\rho$-Nitrophenyl- $\beta$-D-glucuronide (GUR), Pyrrolidonyl- $\beta$-naphthylamide (PYR), Delta-aminolevulinic acid (ALA), Leucine- $\beta$-naphthylamine (LUE), and Leucyl-glycine- $\beta$-naphthylamine (LGLY) showed colors of Yellow, colorless, colorless, yellow, light pink, light pink and yellow respectively as shown in Table 6 .

Table 4. Experimental design for the evaluation of vaccines.

\begin{tabular}{cccccccc}
\hline Groups & Vaccines Birds/Group & $\begin{array}{c}\text { Vaccination } \\
\text { age }\end{array}$ & Marking & Dose/Bird & Toxoids/dose & Vaccine \\
\hline $\begin{array}{c}\text { Group } \\
\text { G1 }\end{array}$ & V1 & 10 & $7^{\text {th }}$ day & Blue head & $0.3 \mathrm{ml}$ & - & AIV OB \\
$\begin{array}{c}\text { Group } \\
\text { G2 }\end{array}$ & V2 & 10 & $7^{\text {th }}$ day & Blue right & $0.3 \mathrm{ml}$ & $91.5 \mu \mathrm{g}$ & AIV OB \\
$\begin{array}{c}\text { Group } \\
\text { G3 }\end{array}$ & V3 & 10 & $7^{\text {th }}$ day & Blue left & $0.3 \mathrm{ml}$ & $22.8 \mu \mathrm{g}$ & AIV OB \\
$\begin{array}{c}\text { Group } \\
\text { G4 }\end{array}$ & $\mathrm{V} 4$ & 10 & $7^{\text {th }}$ day & Red head & $0.3 \mathrm{ml}$ & $11.43 \mu \mathrm{g}$ & AIV OB \\
$\begin{array}{c}\text { Group } \\
\text { G5 }\end{array}$ & - & 10 & $7^{\text {th }}$ day & No Color & - & Control & $\begin{array}{c}\text { No } \\
\text { Vaccine }\end{array}$ \\
\hline
\end{tabular}


Table 5. 96 well plate dilution distribution.

\begin{tabular}{ccccccccccccc}
\hline $\begin{array}{c}1 \text { row } \\
\left(\begin{array}{c}96 \text { well } \\
\text { plate) }\end{array}\right.\end{array}$ & $\mathbf{1}$ & $\mathbf{2}$ & $\mathbf{3}$ & $\mathbf{4}$ & $\mathbf{5}$ & $\mathbf{6}$ & $\mathbf{7}$ & $\mathbf{8}$ & $\mathbf{9}$ & $\mathbf{1 0}$ & $\mathbf{1 1}$ & $\mathbf{1 2}$ \\
\hline $\begin{array}{c}\text { Dilution } \\
\text { factor } \\
\text { (HI Units) }\end{array}$ & $1: 2$ & $1: 4$ & $1: 8$ & $1: 16$ & $1: 32$ & $1: 64$ & $1: 128$ & $1: 256$ & $1: 512$ & $1: 1024$ & $1: 2048$ & $1: 4096$ \\
\hline
\end{tabular}

Table 6. Identification of bacteria by using rapid remel ${ }^{\mathrm{TM}}$ staph plus system penal.

\begin{tabular}{|c|c|c|c|c|}
\hline Sr. \# & Tests & Reactive Ingredients & Colors & Results \\
\hline 1 & $\mathrm{ADH}$ & L-arginine & Purple/blue & + \\
\hline 2 & ODC & L-ornithine & Yellow/straw & - \\
\hline 3 & LIP & Fatty acid ester & Yellow/orange & + \\
\hline 4 & SUC & Sucrose & Yellow/orange & + \\
\hline 5 & MANO & Mannose & Yellow/orange & + \\
\hline 6 & $\mathrm{PO} 4$ & $\rho$-Nitrophenyl-phosphate & Yellow/pale & + \\
\hline 7 & aGLU & $\rho$-Nitrophenyl- $\alpha$, D-glucoside & Yellow/light yellow & + \\
\hline 8 & $\beta \mathrm{GLU}$ & $\rho$-Nitrophenyl- $\beta$, D-glucoside & Yellow/light yellow & + \\
\hline 9 & ONPG & $\sigma$-Nitrophenyl- $\beta$, D-galactoside & Colorless & - \\
\hline 10 & GUR & $\rho$-Nitrophenyl- $\beta$, D-glucuronide & Colorless & - \\
\hline 11 & NAGA & $\begin{array}{c}\rho \text {-Nitrophenyl-N-acetyl- } \beta \\
\text { D-glucosaminide }\end{array}$ & Yellow & + \\
\hline 12 & URE & Urea & Red/dark red/orange & + \\
\hline 13 & PYR & Pyrrolidine- $\beta$-naphthylamine & Yellow/Orange & - \\
\hline 14 & ARG & Arginine- $\beta$-naphthylamine & Purple/light red/dark pink & + \\
\hline 15 & ALA & Alanine- $\beta$-naphthylamine & Yellow/orange & - \\
\hline 16 & LEU & Leucine- $\beta$-naphthylamine & Yellow/orange & - \\
\hline 17 & LGLY & Leucyl-glycine- $\beta$-naphthylamine & Yellow/orange & - \\
\hline 18 & NIT & Potassium nitrate & Cherry red or dark pink & + \\
\hline
\end{tabular}

Based on the physiochemical nature of the isolate such as small rounded translucent colonies, turned cherry red into yellow and observed as small cocci arranged in clusters along with positive for catalase, coagulase, and results from "RapID" Remel" identification kit, it is declared as Staphylococcus aureus. Three $\mathrm{ml}$ of Staphylococcus aureus suspension containing $10^{7} \mathrm{CFU} / \mathrm{ml}$ yields $8.4 \times 10^{13}$ $\mathrm{CFU} / \mathrm{ml}$ in two-liter flask containing Manitol salt broth in digital Bio-fermenter under controlled conditions. Dilutions of bovine serum albumin such as $0 \mu \mathrm{g}$, $20,40,60,80,100,120,140,160,180$ and $200 \mu \mathrm{g}$ at constant value of Bradford reagent $(200 \mu \mathrm{l})$ to distilled water values are $800 \mu \mathrm{l}, 780,760,740,720,700,680$, 
$660,640,620$ and $600 \mu \mathrm{l}$ showed optical density of $0,0.041,0.118,0.158,0.256$, $0.298,0.368,0.485,0.595,0.723$ and 0.828 on the basis of standard curve as shown in Table 7 and Figure 1. It was observed that mean estimated value for one $\mathrm{ml}$ of bacterial free centrifuged supernatant contains $305 \mu \mathrm{g} / \mathrm{ml}$ of SEs.

For the purpose of purification of SEs, dilutions of SEs such as $20 \mu \mathrm{l}, 40 \mu \mathrm{l}$ and $60 \mu \mathrm{l}$ at the constant value of $5 \mathrm{X}$ loading dye $(20 \mu \mathrm{l})$ to distilled water $60 \mu \mathrm{l}, 40 \mu \mathrm{l}$ and $20 \mu \mathrm{l}$ run on the SDA-PAGE along with standard marker showed that molecular weight of enterotoxins was $28 \mathrm{kDa}$ as shown in Figure 2.

Table 7. Bovine serum albumin standard curve values.

\begin{tabular}{ccccc}
\hline Sr. \# & $\begin{array}{c}\text { Bovine Serum } \\
\text { Albumin }(\mu \mathrm{g} / \mu \mathrm{l})\end{array}$ & $\begin{array}{c}\text { Distilled Water } \\
(\mu \mathrm{l})\end{array}$ & $\begin{array}{c}\text { Bradford Reagent } \\
(\mu \mathrm{l})\end{array}$ & $\begin{array}{c}\text { O.D } \\
(595 \mathrm{~nm})\end{array}$ \\
\hline 1 & 0 & 800 & 200 & 0 \\
2 & 20 & 780 & 200 & 0.041 \\
3 & 40 & 760 & 200 & 0.118 \\
4 & 60 & 740 & 200 & 0.158 \\
5 & 80 & 720 & 200 & 0.256 \\
6 & 100 & 700 & 200 & 0.298 \\
7 & 120 & 680 & 200 & 0.368 \\
8 & 140 & 660 & 200 & 0.485 \\
9 & 160 & 640 & 200 & 0.595 \\
10 & 180 & 620 & 200 & 0.723 \\
11 & 200 & 600 & 200 & 0.828 \\
\hline
\end{tabular}

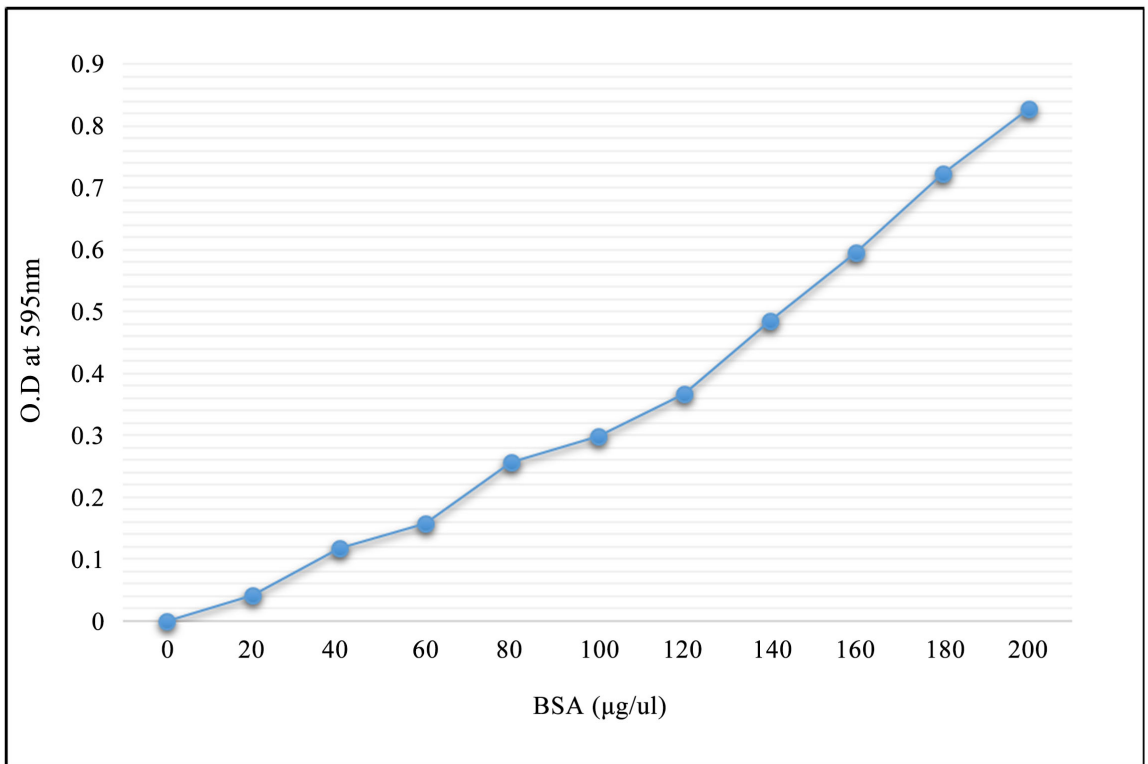

Figure 1. Bradford assay bovine serum albumin standard curve. 


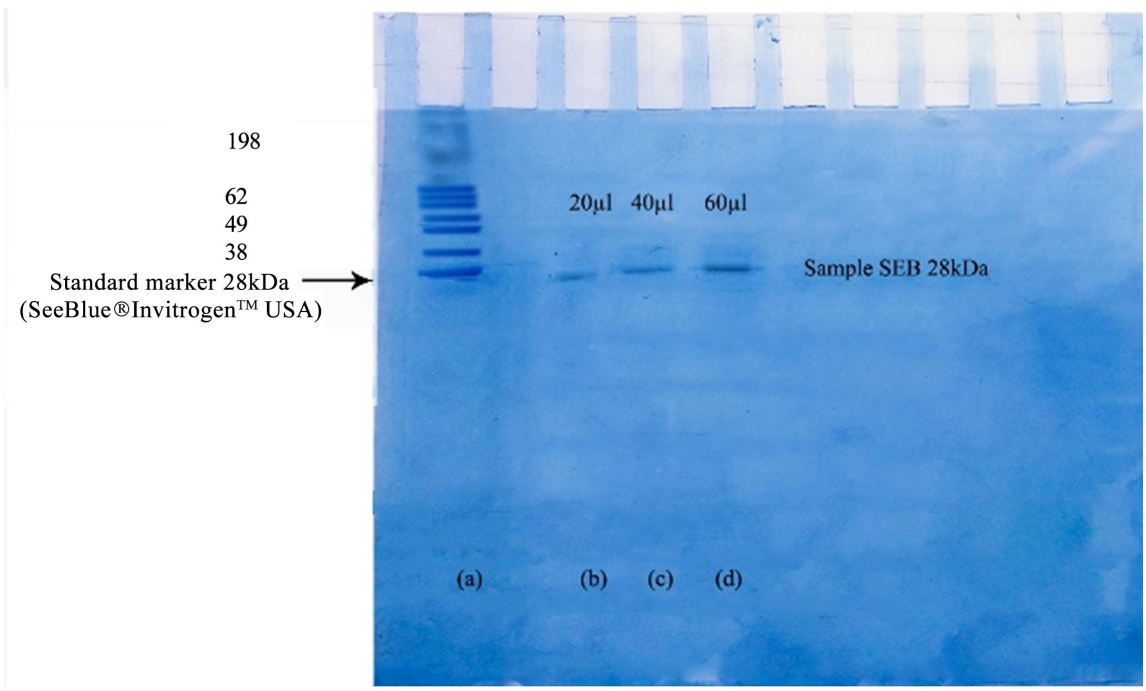

Figure 2. SDS-PAGE, (a) standard Marker; (b) $20 \mu \mathrm{l}$ sample; (c) $40 \mu \mathrm{l}$ sample and (d) 60 $\mu \mathrm{l}$ sample.

\section{Immunomodulatory Effect of SEs with Avian Influenza Emulsified Vaccine}

Avian influenza $\mathrm{H} 9 \mathrm{H} 2$ emulsion was stable after centrifugation and showed uniform particle size and its distribution on slide under microscopy. The viscosity of the emulsion sample was $75 \mathrm{mPa} \cdot \mathrm{s}$ (millipascal second) at $60 \mathrm{rpm}$ and $30^{\circ} \mathrm{C}$. Detectable anti-influenza $\mathrm{H} 9-\mathrm{HI}$ antibodies against oil based vaccines having immunogen level of $\operatorname{EID}_{50}=10^{9.5} / \mathrm{ml}$ and $\mathrm{HA}=9(512 \mathrm{HAU})$ containing different concentration of SEs toxoids were monitored at different time intervals such as $8^{\text {th }}, 16^{\text {th }}$ and 32 -day post vaccination.

It was observed that on $8^{\text {th }}$ day post vaccination, mean anti AIH9 HI antibody titer of eight birds of G-1, G-2, G-3, G-4 and G-5 was $2.13 \pm 0.354,3.50 \pm 0.926$, $3.13 \pm 1.126,2.63 \pm 0.518,1.25 \pm 1.035$ respectively (Figure 3 ) Similarly, on 16-day post vaccination mean anti AIH9 HI antibody titer of G-1, G-2, G-3, G-4 and G-5 was $3.00 \pm 0.926,4.63 \pm 0.518,3.50 \pm 0.756,3.00 \pm 1.069$ and $0.63 \pm$ 0.744 respectively (Figure 4) whereas, on 32-day post vaccination mean anti AIH9 HI antibody titer of G-1, G-2, G-3, G-4 and G-5 was $4.25 \pm 0.707,7.25 \pm$ $0.707,5.25 \pm 1.035,4.13 \pm 0.641,0.00 \pm 0.000$ (Figure 5). Moreover, on 32-day post vaccination cumulative mean anti AIH9 $\mathrm{HI}$ antibody titer of G-1, G-2, G-3, G-4 and G-5 was $3.13 \pm 0.406,5.13 \pm 0.246,3.96 \pm 0.159,3.25 \pm 0.237$ and $0.78 \pm$ 0.467 respectively. It was found that all the vaccines induced protective titers on 18 days' post vaccination but vaccine containing $91.5 \mu \mathrm{g} / \mathrm{ml}$ of SEs toxoid showed significantly higher $(\mathrm{P}<0.05)$ anti $\mathrm{H} 9-\mathrm{HI}$ antibody titer as compared to vaccine containing $22.8 \mu \mathrm{g} / \mathrm{ml}$ and $11.43 \mu \mathrm{g} / \mathrm{ml}$. whereas, vaccines containing SEs toxoid showed better $(\mathrm{P}<0.05)$ anti AIH9 $\mathrm{HI}$ antibody titer as compared to vaccine injected without SEs toxoid. Cumulative immunomodulatory effects of SEs in avian influenza vaccinated birds are described in (Figure 6).

Super antigens are the biological products which stimulate large number of T-Cells unlikely to that of conventional antigens. These immunogenic and dis- 
ease causing small proteins are secreted by group of Gram positive bacteria implying role in facilitating body own defense system. Co-administration of the staphylococcal enterotoxins B (SEB) augments the immunogensis process of particular antigen [10]. In the current study Staphylococcus aureus was isolated

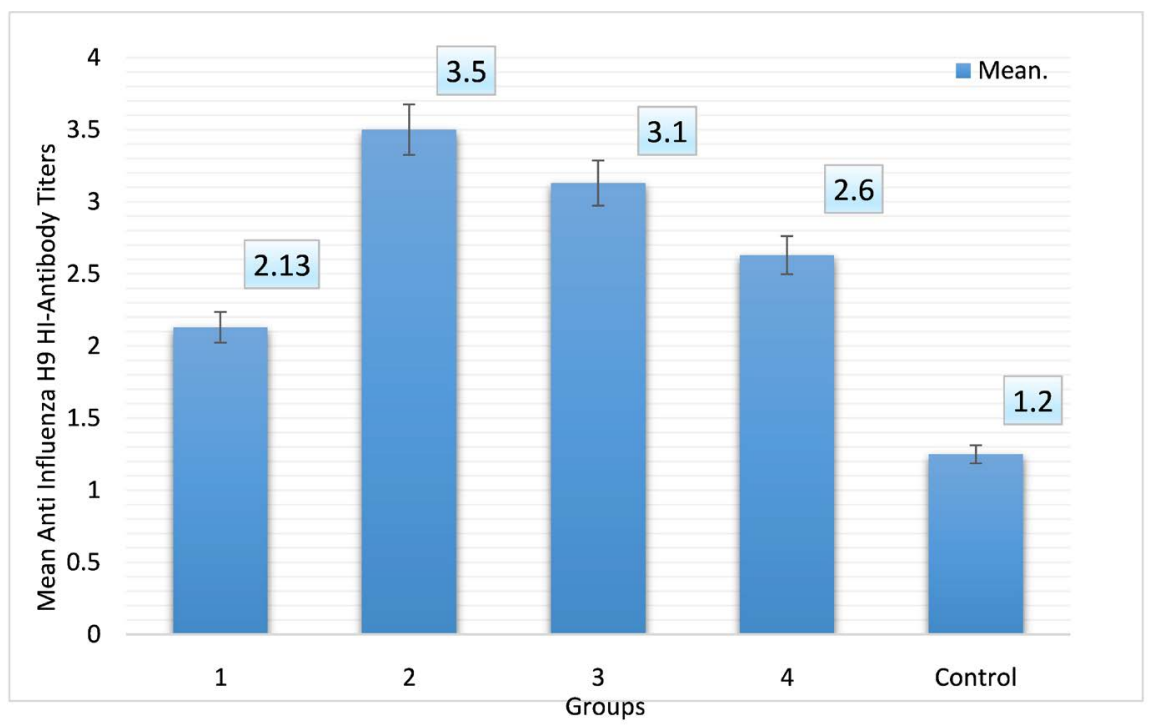

Figure 3. Mean anti-influenza-H9 antibody titers $8^{\text {th }}$ DPV, Group $1=$ Injected with Inactivated O/B H9 Vaccine, Group 2 = Injected with Inactivated O/B H9 Vaccine with $91.5 \mu \mathrm{g}$ Staphylococcal Toxoids, Group 3 = Injected with Inactivated O/B H9 Vaccine with $22.8 \mu$ g Staphylococcal Toxoids, Group $4=$ Injected with Inactivated O/B H9 Vaccine with $11.43 \mu \mathrm{g}$ Staphylococcal Toxoids and Group 5 = Control (No Vaccine).

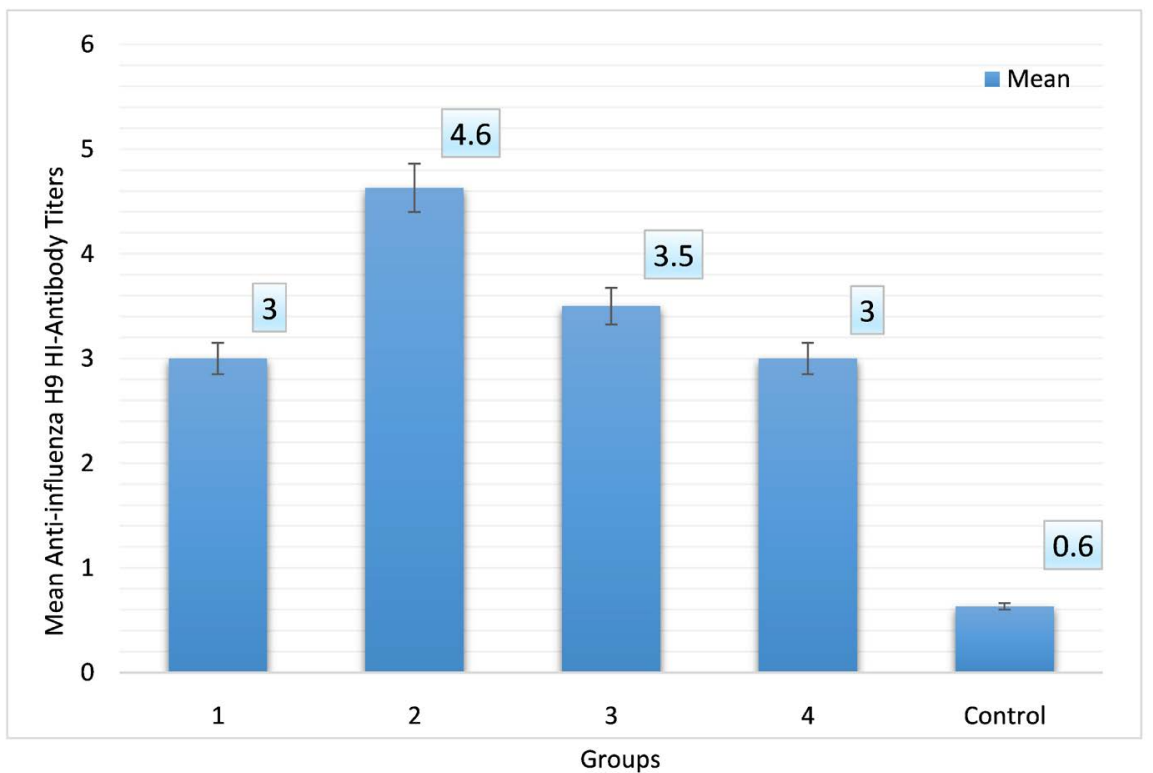

Figure 4. Mean anti-influenza-H9 antibody titers $16^{\text {th }} \mathrm{DPV}$, Group $1=$ Injected with Inactivated O/B H9 Vaccine, Group 2 = Injected with Inactivated O/B H9 Vaccine with $91.5 \mu \mathrm{g}$ Staphylococcal Toxoids, Group 3 = Injected with Inactivated O/B H9 Vaccine with $22.8 \mu \mathrm{g}$ Staphylococcal Toxoids, Group $4=$ Injected with Inactivated O/B H9 Vaccine with $11.43 \mu \mathrm{g}$ Staphylococcal Toxoids and Group 5 = Control (No Vaccine). 


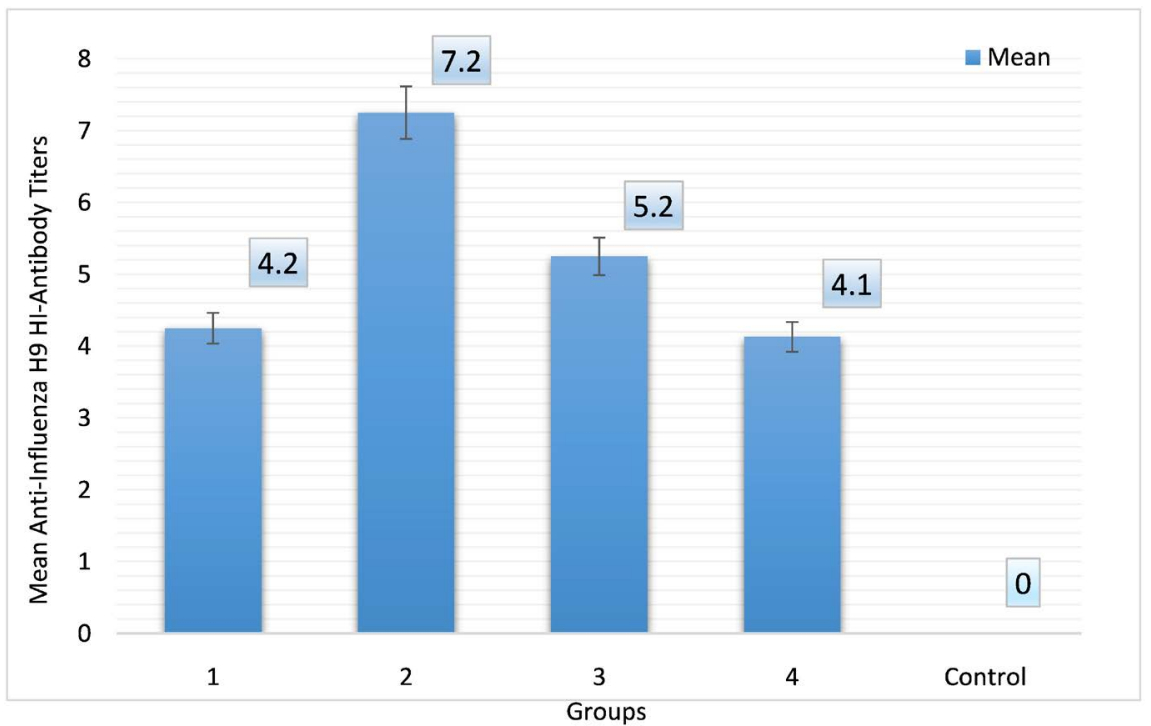

Figure 5. Mean anti-influenza-H9 antibody titers $32^{\text {nd }} \mathrm{DPV}$, Group $1=$ Injected with Inactivated O/B H9 Vaccine, Group 2 = Injected with Inactivated O/B H9 Vaccine with $91.5 \mu \mathrm{g}$ Staphylococcal Toxoids, Group 3 = Injected with Inactivated O/B H9 Vaccine with $22.8 \mu \mathrm{g}$ Staphylococcal Toxoids, Group $4=$ Injected with Inactivated O/B H9 Vaccine with $11.43 \mu \mathrm{g}$ Staphylococcal Toxoids and Group 5 = Control (No Vaccine).

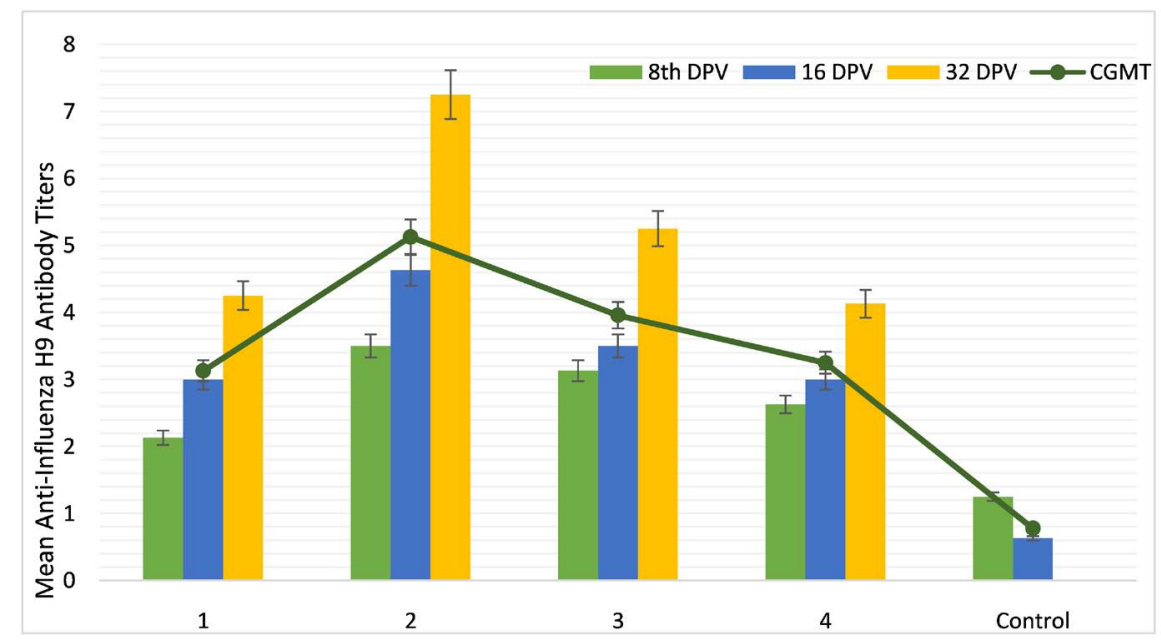

Figure 6. Cumulative mean anti-influenza-H9 antibody titers, Group $1=$ Injected with Inactivated O/B H9 Vaccine, Group 2 = Injected with Inactivated O/B H9 Vaccine with $91.5 \mu \mathrm{g}$ Staphylococcal Toxoids, Group $3=$ Injected with Inactivated O/B H9 Vaccine with $22.8 \mu \mathrm{g}$ Staphylococcal Toxoids, Group $4=$ Injected with Inactivated O/B H9 Vaccine with $11.43 \mu \mathrm{g}$ Staphylococcal Toxoids and Group $5=$ Control (No Vaccine).

from the yogurt samples by using tryptone agar medium. Microscopic investigation revealed gram positive cocci arranged in cultures under 100X oil immersion lens. Biochemical analysis of the pure culture showed positive results for indole, catalase, urease and production of acid with gas [11]. Pure culture of Staphylococcus aureus containing $1 \times 10^{9} \mathrm{CFU} / \mathrm{ml}$ was injected into five liter of autoclaved nutrient broth supplied with continuous aeration and agitation in 
bio-fermenter at $37^{\circ} \mathrm{C}$ produced profound turbidity [4]. Ultracentrifugation at $56,100 \mathrm{rpm}$ for 20 minutes pelleted the bacteria while toxins were recovered from the supernatant [5]. Bacterial free supernatant was estimated for the quantification of toxins using Bradford protein assay [6] and identification by polyacrylamide gel electrophoresis [12]. Thus, another profound quantity of staphylococcal enterotoxins (SEs) recovered from the bacterial fermentation was processed for the formulation of oil based avian influenza inactivated vaccines containing different toxoid concentration. Each of the formulation was evaluated in broiler birds in terms of Hemagglutination inhibition test [9]. It was observed that concentration of staphylococcal toxoid greatly affects the immunogenic potential of avian influenza antigen. Oil based avian influenza H9 inactivated vaccine in association with $91.5 \mu \mathrm{g} / \mathrm{ml}$ of SE toxoid induced detectable anti AIVH9-HI antibody titer in broiler birds at $8^{\text {th }}$ day post vaccination which gradually increases and reached peak on 32-day post vaccination. The humoral immunity is directly proportional to concentration of SEs up to $91.5 \mu \mathrm{g} / \mathrm{ml}$. In this experiment oil based vaccine containing $91.5 \mu \mathrm{g} / \mathrm{ml}$ of SE toxoid induced significantly higher anti AIV-H9-HI anti-body titers as compared to the rest of concentrations of the SE (Figure 6).

The protein antigens of the vaccines are processed by local antigen processing and presenting cells (APC) such as macrophages, dendritic cells or B cells and present the processed antigen on its surface on association with class MHC-II antigen/immune associated antigen ( $\mathrm{Ia} \mathrm{Ag)} \mathrm{[13].} \mathrm{Avian} \mathrm{T}$ helper $\left(\mathrm{T}_{\mathrm{h}}\right)$ cells can only recognize the foreign specific antigen associated with Ia antigen on surface of the APC and undergo the process of blast formation, proliferation, differentiation into effector and memory cells. The effector cells those survives up to seven days secrete cytokines such as IL-2, IL-4, IL-5, INF- $\gamma$ etc. production of the cytokines is antigen specific and their action is antigen nonspecific so, these cytokines now specifically activates macrophages, Natural killer (NK) cells, Cytotoxic T cells (Tc), B cells etc. in this way cytokines potentiate the specific and nonspecific immune responses of the vaccinated birds. Similarly, avian bursal dependent lymphocytes (B cells) recognize specific free antigen from the inoculation site (processed/non-processed through APC) and undergo the process of blast formation, proliferation and differentiation into plasma cells without development of memory cells. However, the cytokines produced by the effector cell potentiate the activity of $\mathrm{B}$ cells/enhance the humoral immune response to vaccinal immunogens in following five ways. Cytokines increase proliferation of $B$ cells, differentiate the proliferated cells into memory and plasma cells, augment shelf life of the plasma cells, switching over of IgM to IgG or IgA production and increase antibody synthesis rate of the plasma cells.

Staphylococcal exotoxins such as enterotoxins A and B (SEA and SEB) with distantly having similar structure toxic shock syndrome toxin (TSST) are superantigens that potently stimulate $\mathrm{T}$-cell proliferation and cytokine production [14]. These toxins bypass the normal antigen processing and presentation process of immunogenesis, limiting the time of mounting immune response. 
They bind directly with the major histocompatibility complex (MHC) class II molecules on antigen-presenting cells (APC) and subsequently interact with specific $\mathrm{V} \beta$ regions of the T-cell antigen receptors [4] [15] [16]. Most of the studies revealed that these small highly immunogenic proteins induce variety of proinflammatory mediators such as gamma interferon (IFN- $\gamma$ ), interleukin 6 (IL-6), IL-1 and tumor necrosis factor (TNF- $\alpha$ ) high level [17] [18]. All these mediators have been involved the inflammatory response thus by stimulating the cellular response of the body [19]. In normal conditions action of these cytokines are immunostimulatory by promoting the leucocyte and cellular reaction, but at high concentration IL-1 and TNF- $\alpha$ will results in raising of fever and consequently induce toxic shock syndrome by SEs.

\section{Conclusion}

This study demonstrated that estimated dose of SE toxoid effectively induced the production cytokines, particularly IL- 1 and IL- 6 by macrophage and T-helper cell respectively, which is indicated indirectly by the production of antibodies. The induction of cytokines in controlled manner augments the process of proliferation and differentiation of lymphocytes, which results into rapid production of antibodies by plasma cells in broiler birds. This co-stimulatory effect of pro inflammatory mediators triggers the nonspecific inhibitors of the immune system including natural killer cell and monocytes. On the basis of evaluation of humoral response measured in term of $\mathrm{HI}$ titers, it could be assumed that purified SE toxoid has co-stimulatory effect on oil based influenza vaccine which augments proliferation of lymphocytes by activation of APC and T cells along with production of cytokines. In conclusion, the promising findings of this study suggest that calculated amount of purified SE toxoid is a potential immuno-modulatory agent when used along with proteinous antigen such as influenza viruses.

\section{Acknowledgements}

The authors gratefully acknowledge financial support from the Ottoman Pharma (immuno Division). In addition, we wish to thank Prof. Dr. MH Qazi [Late] who made valuable suggestions contributed to the preparation of the manuscript.

\section{Conflicts of Interest}

The authors declare no conflicts of interest regarding the publication of this paper.

\section{References}

[1] Brehm, R.D., Tranter, H.S., Hambleton, P. and Melling, J. (1990) Large-Scale Purification of Staphylococcal Enterotoxins A, B, and C2 by Dye Ligand Affinity Chromatography. Applied and Environmental Microbiology, 56, 1067-1072.

[2] Herman, A., Kappler, J.W., Marrack, P. and Pullen, A.M. (1991) Superantigens: 
Mechanism of T-Cell Stimulation and Role in Immune Responses. Annual Review of Immunology, 9, 745-772. https://doi.org/10.1146/annurev.iy.09.040191.003525

[3] Bergdoll, M.S. (1983) Enterotoxins. Staphylococci and Staphylococcal Infections, 2, 559-598.

[4] Jarvis, A.W., Lawrence, R.C. and Pritchard, G.G. (1973) Production of Staphylococcal Enterotoxins A, B, and C under Conditions of Controlled $\mathrm{pH}$ and Aeration. Infection and Immunity, 7, 847-854.

[5] Arbuthnott, J.P., Freer, J.H. and Bernheimer, A.W. (1967) Physical States of Staphylococcal $\alpha$-Toxin. Journal of Bacteriology, 94, 1170-1177.

[6] Bradford, M.M. (1976) A Rapid and Sensitive Method for the Quantitation of Microgram Quantities of Protein Utilizing the Principle of Protein-Dye Binding. Analytical Biochemistry, 72, 248-254. https://doi.org/10.1016/0003-2697(76)90527-3

[7] Pollack, M. and Prescott, R.K. (1982) Toxoid from Exotoxin A of Pseudomonas aeruginosa: Preparation and Characterization. Journal of Infectious Diseases, 145, 688-698. https://doi.org/10.1093/infdis/145.2.688

[8] Tahir, M., Mehmood, D., Sultan, A., Saeed, M., Khan, A., Ansari, F., et al. (2016) A Modified Strategy of Multiplex RT-PCR for Simultaneous Detection of H5, H7, and H9 Subtypes of Avian Influenza Virus Based on Common Forward Oligo. Journal of Applied Poultry Research, 25, 322-327. https://doi.org/10.3382/japr/pfw014

[9] Javed, M., et al. (2014) Comparative Evaluation of Conventional and Molecular Diagnostic Methods for Newcastle Disease during an Outbreak in Punjab, Pakistan. Pakistan Journal of Agricultural Sciences, 51, No. 3.

[10] Niedergang, F., Hemar, A., Hewitt, C.R.A., Owen, M.J., Varsat, A.D. and Alcover, A. (1995) The Staphylococcus aureus Enterotoxin B Superantigen Induces Specific T Cell Receptor Down-Regulation by Increasing its Internalization. Journal of Biological Chemistry, 270, 12839-12845.

[11] Baird-Parker, A. (1963) A Classification of Micrococci and Staphylococci Based on Physiological and Biochemical Tests. Microbiology, 30, 409-427.

[12] Lee, K.K., Yu, S.R. and Liu, P.C. (1997) Alkaline Serine Protease Is an Exotoxin of Vibrio Alginolyticus in Kuruma Prawn, Penaeus japonicus. Current Microbiology, 34, 110-117. https://doi.org/10.1007/s002849900153

[13] Wu, J.Y., et al. (1994) Hormonal Regulation of the Gene for the Type C Ecotropic Retrovirus Receptor in Rat Liver Cells. Journal of Virology, 68, 1615-1623.

[14] Kotzin, B.L., Leung, D.Y.M., Kappler, J. and Marrack, P. (1993) Superantigens and Their Potential Role in Human Disease. Advances in Immunology, 54, 99-166. https://doi.org/10.1016/S0065-2776(08)60534-9

[15] Parsonnet, J., Hickman, R.K., Eardley, D.D. and Pier, G.B. (1985) Induction of Human Interleukin-l by Toxic-Shock-Syndrome Toxin-1. Journal of Infectious Diseases, 151, 514-522. https://doi.org/10.1093/infdis/151.3.514

[16] Scholl, P., Diez, A., Mourad, W., Parssonnet, J., Geha, R.S. and Chatila, T. (1989) Toxic Shock Syndrome Toxin 1 Binds to Major Histocompatibility Complex Class II Molecules. Proceedings of the National Academy of Sciences, 86, 4210-4214. https://doi.org/10.1073/pnas.86.11.4210

[17] Miethke, T., Wahl, C., Regele, D., Gaus, H., Heeg, K. and Wagner, H. (1992) T Cell-Mediated Lethal Shock Triggered in Mice by the Superantigen Staphylococcal Enterotoxin B: Critical Role of Tumor Necrosis Factor. Journal of Experimental Medicine, 175, 91-98. https://doi.org/10.1084/jem.175.1.91

[18] Stiles, B., Bavari, S., Krakauer, T. and Ulrich, R. (1993) Toxicity of Staphylococcal 
Enterotoxins Potentiated by Lipopolysaccharide: Major Histocompatibility Complex Class II Molecule Dependency and Cytokine Release. Infection and Immunity, 61, 5333-5338.

[19] Krakauer, T. and Stiles, B.G. (1999) Pentoxifylline Inhibits Superantigen-Induced Toxic Shock and Cytokine Release. Clinical and Diagnostic Laboratory Immunology, 6, 594-598. 